\title{
Capacity Apparatus Improvement in Managing Economics and Finance towards Independent Village
}

\author{
Rahima Br. Purba \\ Faculty of Economics Universitas Pembangunan Panca Budi Jl. Jend. Gatot Subroto Km. 4,5 Sei Sikambing, \\ 20122, Medan, Sumatera Utara, Indonesia
}

\begin{abstract}
In the general provisions of Permendagri 37/2007, it tells that the village is the overall financial management activities include: planning, budgeting, administration, reporting, accountability and financial oversight of the village. With the autonomous rights, the village is expected to manage its finances independently, better manage revenue and income sources also manage the budget expenditures. The purpose of this study was to describe the condition of financial management "Cempa Village" and "Sukadamai Village" in the district of Hinai, Langkat. To determine the extent to understanding whether village officials on the management of village finances effectively and efficiently to realize independent village, the research method used in this research is using a qualitative approach. The results of this study are the village can run the management of development independently; not only capable of moving the entire resource assets owned by the village. The village will also be able to fix the basic needs of citizens, livelihood needs, fight for the residents and manage life in a sustainable manner, the position and authority of the village. It is an essential element to realize the independence of the village, the challenges facing the village of RPJM, RKP, and APB until the village accountability report. Local authorities also coordinate with the village regarding providing assistance and training to increase the capacity of village officials.
\end{abstract}

Keywords: Financial, Management, Village

\section{Introduction}

Village, in Act No. 22 of 1999 [6] on Regional Government that the village is the unity of the legal community who has the authority to regulate and manage the interests of local communities based on the origin and the local customs are recognized in the system of National Government. In the Regency, whereas in Law Number 32 Year 2004 on Regional Government, the Village is a community unit which has boundaries that are authorized to regulate and manage the interests of local communities. It is based on the origins and customs of the place that is recognized and respected by the Government administration system Unitary Republic of Indonesia. In a sociological perspective, the village is a community that occupies a particular area where people know each other well, patterned homogeneous, and much depends on nature.

Sutoro said discussions linking the village to the topic of democracy is viewing village as a mini republic who could carry out maintenance of free and democratic turnover of leadership [2]. The village is a self-contained tiny republic. The size is not emphasized in the fulfillment of the three branches of power namely the legislative, executive and judicial. The size is imposed on the democratic culture which allegedly has long nurtured and cared for by the village. Therefore, the institutionalization of democratic culture and traditions of the village is considered more important than the setting and the creation of formal institutions of democracy.

The regulation provides the foundation for the most autonomous village in practice, not just a normative. With the granting of financial management authority of the community (by Permendagri 37/2007) and the allocation of village funds (based on PP 72/2005), the village should become more open (transparent) and responsive to the financial management process. In the general provisions of Permendagri 37/2007, it is submitted that the village is the overall financial management activities [6]. It includes planning, budgeting, administration, reporting, accountability and financial oversight of the village. The autonomous rights of the village are expected to manage its finances independently, better manage income and sources of income. It also manages the budget expenditures. But in fact, many villages that have not been able to take advantage of these benefits, dependence on funding from the central government and local government is unyielding. The village has not been able to optimize revenue sources based on the village by the wealth and potential of the village.

Formulation and implementation of the Budget of the Village (APBDes) should be filled with activities/programs needed by the people is not realized. For example, physical development activities are not carried out by those contained in the APBDes, instances of fraud seen from the difference in volume, quality, price and so on. Researchers conducted an analysis on two villages in the district Hinai, Langkat, North Sumatra, Cempa and Suka Damai. The reason the two villages were used as the research object because the area is in desperate need consideration and input for the planning, program evaluation, and also related to the development of the area. 


\section{Theories}

\section{A. Village Governance}

The village is the unity of the legal community who have the authority to regulate and manage the interests of local communities based on the origin and the local customs are recognized in the national administration system and is located in the district. The formulation of the definition of a complete village is in the Act No. 22/1999 on local government: "Village or called by another name as a legal community unit which has the original order based on rights that are the origin of privilege within the meaning of explanation of Article 18 of the 1945 Constitution. The rationale in village governance arrangements is diversity, participation, genuine autonomy, democratization and empowerment In Act No. 22 of 1999 on Regional Government states that the village is the unity of the legal community who has the authority to regulate and manage the interests of local communities based on the origin and the local customs are recognized in the system of the National Government and the Regional District. In Law Number 32 Year 2004 on Regional Government, the Village is a community unit which has boundaries that are authorized to regulate and manage the interests of local communities, based on the origins and customs of the place that is recognized and respected in the governance system of the Republic of Indonesia.

\section{B. Variables}

Based on Government Regulation (PP) No. 24 of 2005 concerning Government Accounting Standards (SAP), it is explained that the budget is a guideline measures to be implemented by the government include a plan revenues, expenditures, transfers, and financing are measured in rupiah. It is arranged according to specific classification is systematically for a period. According to Nordiawan, a budget is a plan of financial stating plans of the organization to serve the community or other activities that can develop organizational capacity in service, an estimate of costs to be incurred in realizing the plan, the estimated sources anywhere that will generate income and how much of that income. According to Halim [10], the budget is an operational plan that is expressed in a currency of an organization where a party or reception illustrates the expected revenue to cover the expenses for a given period is one year. According to Munandar, the budget is a plan drawn up systematically covering all activities of the company, which is expressed in monetary units and is valid for a certain period to come. According to Freeman, translated by Nordiawan, Son, and Rahmawati, a budget is a process undertaken by an organization to allocate its resources to the needs that are not restricted (the process of allocating resources to unlimited demands).

\section{Villages Description}

Based Statistical Area District of Hinai 2015, Cempa Village is the second village which has the largest population in the district Hinai (2014). It is also the second village that has the largest number of households in the district Hinai (Year 2008). The village has 39 hectares of paddy fields, instead of paddy land area 857 ha, and non-agricultural land area of 122 hectares (2014). Based Statistical Area District of Hinai 2015, Sukadamai Village is the third village which has the largest population in the district Hinai (2014). The village has 75 hectares of paddy fields. The non-paddy land area is 13 hectares and non-agricultural land area of 36 ha (2014).

\section{Methodology}

The method used in this research is using a qualitative approach. With an emphasis on the process, then search the data, and information will be made to know and understand about the financial management of the village that had been taking place. Data will be collected from two sources: a source of primary data and secondary data sources. Primary data obtained through the technique of in-depth interviews and participant observation. It aims to capture information about the financial management of the village and sharpened the focus group discussion technique. FGD technique was used to obtain a draft model of financial management of the village.

The research location is set in the District Hinai, Langkat, North Sumatra province (Cempa and Suka Damai). The analysis used simultaneously by using the method of analysis going on. Any new information will be analyzed, the inferences are used to build and sharpen the questions on the next day. The analysis was carried out following the process of presenting the data and drawing conclusions based on the data presentation is performed during the data collection process takes place. For qualitative data collection is the village officials in the District Hinai, Langkat district of North Sumatra province as well.

\section{A. Applications built Budgets Arrangement}

Budgets must be thorough and achievable. In the budget, there should be innovation and flexibility to deal with events that are not predictable. Budgeted figures can be expressed in dollars, units, clock, pound, and employees. Shim and Siegel stated a budget must have the following characteristics:

1. The predictive ability 
2. Communication channels, powers, and responsibilities clearly

3. The information that is accurate and timely

4. Compliance, comprehensive, and clarity of the information

5. Support in the organization of all parties involved

The steps to be followed in budgeting include:

1. Setting goals

2. Evaluating the resources available

3. Negotiations between the parties involved regarding the budget figures

4. Coordination and review of the components

5. Final approval

6. Distribution of the approved budget.

\section{B. Budget Analysis}

According to Shim and Siegel [9], in analyzing the budget, the actual figures should be compared with the budgeted figures and the reason for the variance is known, along with the cause (responsible parties). Variances sales can be separated based on sales volume and selling prices while the cost variance consists of price and quantity.

Profit variance consists of the variance of sales and costs. Managers must find ways to improve profitability, such as taking into account the relationship between the variance [1]. For example, there is unfavorable variance in the price of materials arising from the rising price of materials. It turned out that the increase in material prices due to increase in material quality. Increasing the quality of material will produce a variance amount of material and the amount of labor that is profitable [3]. The net result is profitable and ultimately have an impact on the increase in net income (earnings).

Unfavorable variance must be corrected. For example, if the price of raw material becomes extremely higher than expected, then it must find a cheaper supplier. Inefficiency, in any case, must be corrected. A budget should have variances that allow an increase in unfavorable variances in the budget. It can come from unexpected salary increases, raw material prices higher, and the incremental costs that occur when there is a mass strike. Managers must be able to decide the allocation of the excess costs appropriately.

\section{Budgetary Control}

According to Shim and Siegel (2000), the budget control internal factors, more labor can be controlled by managers as compared to external factors such as inflation or competition. When under control, corrective measures can be taken. At the beginning of the period, the budget is a plan. At the end of the period, the budget is a tool to measure the performance compared to the control over the plan, so that the performance in the future can be improved. A budget is a tool of control for income, expenses, and operations. There should be a budgetary control to financial and nonfinancial activities (such as product life cycle, seasonal). Control is achieved through progress reporting and actual spending compared to plan (budget) continuous [5]. An inputoutput relationship should also be considered. Assessment costs (cost appraisal) and control policies should be implemented to ensure that the project will be profitable.

\section{Transparency}

According to Mardiasmo [7], the notion of transparency is "Openness government in making policies of local finance that can be known and monitored by the legislature and the public." According to Nordiawan [8], he stated, "Transparency provide financial information that is open and honest with the public based on the consideration that the public has a right to find out openly and comprehensively on government accountability in the management of the resources entrusted to him and his obedience to the laws and regulations." From the description, it can be concluded, that the transparency of a country can be created if the state governance system provides the freedom for people to obtain the information needed by the public.

\section{E. Accountability}

Good governance is one of the community's guidance that must be met. One of the pillars of governance is accountability. Mardiasmo said, "Public accountability is the obligation of a fiduciary to provide accountability, present and disclose all its activities and the activities that its responsibility to the party giving the mandate (Principal) who has the right and authority to request such accountability." Nordiawan said, "Accountability is a step to account for resource management and policy implementation is entrusted to entities reporting in achieving the goals set periodically." As has been described, according to some definitions of Mardiasmo explained there are five dimensions of accountability that must be met by public sector organizations, such as: 
1. Financial Accountability, it is related to the avoidance of misuse of public funds

2. Honesty and Accountability Law Accountability, it is about the avoidance of abuse of office, while the legal accountability associated with the guarantee with their compliance with laws and regulations that are not required in the use of public funds

3. Accountability Process, it is related to whether the procedures used in carrying out the task has been quite good regarding adequacy of accounting information systems, management information systems, and administrative procedures

4. Accountability Program, it is related to consideration of whether the objective set can be achieved or not, and whether it has considered alternative programs that provide optimal results with minimum costs

5. Policy Accountability, it is related to government, both central and local levels on policies taken by the government to DPR/DPRD and the wider community.

Based on some of the above definitions, the central government, and local government is expected to present the financial statements consisting of the surplus/deficit, Budget Realization Statement, Balance Sheet and Notes to Financial Statements. These financial statements are an essential component to creating the accountability of the public sector and are one of the Financial Central Government and the Regions performance measures.

\section{Evaluation}

The ability to manage more independent development supported by all of the elements and resources of the village is very important for improving the welfare of the community, especially for the rural poor. The village that can run independently of development management not only to manage the entire asset resources owned by the village, but the village will also be able to fix the basic needs of citizens, livelihood needs, and to organize the fight for citizens in a sustainable manner.

The status and authority of the village is an important element to realize the independence of the village. In everyday conversation, the position and authority of the village is a concept that is not simple to be understood by the village administration, village institutions, community organizations and village communities. In general, villagers are more familiar with the village planning and budgeting, women's empowerment or services to citizens, compared to the position and authority of the village.

If the position and authority are unclear and not well understood by the components of the village, the governance, planning, and budgeting, as well as service to the community, tend to run by the habits inherited. The head of the village and the village is working to serve the community 24 hours nonstop and is constantly running the administrative tasks of the government administration and development. But from the first also walking routine like that, so many people ask what is the nature and benefits of communities on local.

Law No. 6 of 2014 confirms the status and authority of the village. The village law, which will be further elaborated by the government regulation, the regulation must be complied with by the government and by the village, as well as guided directions to ascertain the limits and the type of village authority. In the early stages of understanding of the position of the village as well as understanding and kind authority of the village and its consequences should be well understood by the village government and institutions in the villages and rural communities, which are then applied in the system of village government. UU no. 6/2014 on village contains a noble mission: to protect and empower the state to be strong, advanced, independent, and democratic so as to create a solid foundation in implementing governance and development towards a just, prosperous, and prosper. Independence of the village fronted village law for two reasons.

First, the village is weak and dependent, do not have a clear position and authority, or banya assumed an obligation rather than authority; became the object of politicization and development, and do not become state assets, but borne by the state. Second, contrary village UU brings the spirit and purpose of reinforcing the village; clarifies the status and authority of the village; make the village as the subject of development; as well as the village to be an asset for the country that has contributed to the ideals of the people's welfare.

Regarding the norms and laws, the status and authority of the village are the heart of the independence of the village. UU no. 6/2014 has confirmed the position and authority of the village are much more clear and powerful than the regulations in Law No. 32/2004.

\section{A. Rural Financial Management Condition}

Management of village finances can not be separated from a series of annual village planning process. This is called Musrenbangdes. Output of Musrenbangdes is a document Budget village. The main base is a document preparation APB Development Plan and RKP. Management of village finances is a unity that is inherent in the implementation of village autonomy to the independence of the village. Village financial management aims to create and strengthen the system of village governance that clearly and effectively to realize a better accountability in the exercise of government. 
Finance could be a blessing but it can also be disastrous. Finance becomes mercy when, first administered in accordance with the provisions of the legislation so that finance can create overall rural development and improve people's welfare. Second, the financial allocation is used for the welfare of the village society, especially the poor, women and children, with the involvement of the group in the drafting process and the budget approval.

If the village finances are not managed under the provisions of the legislation it can lead to actions that lead to financial abuse, either as individuals or groups. This will result in a loss of public confidence to the village government. Development will not run properly and potentially against the law. Managing the financial system is not a tough job, but also not the job lightly. The required accuracy, dexterity and seriousness, especially in the rural financial system has not been implemented systematically. The spirit of independence of the village who are mandated in the Act No.6 / 2014 of the Village is expected to be a motivation for the establishment of village autonomy, the village was able to manage his own household.

To realize the independence of the village, the village must do a thorough reform [4]. The village should be able to draw up development plans in the form of APB. Planning and budgeting aim to be able to manage the rural village budget planning and public favor.

There are two challenges in Cempa and Suka Damai. First, in RPJM, people have been suspicious of the plan the use of these funds. So village officials should be more detailed in describing plans for the utilization of the village. Second, Sukadamai village led by the village chief who is not from people who understand the finances. These villages have much to learn from a neighboring village.

The local and Rural companion should also be more active in providing assistance to the village. Especially with the Rural Financial System, a tool or application that makes it easy for village officials from the start RPJM, APB, Financial Administration and Financial Accountability village issued from BPKP (Financial and Development Supervisory Agency).

\section{B. Understanding of Financial Management Apparatus}

Along with the growing attention of the government to the village, the village must constantly be updated with info associated with it including the village officials as the manager of the village finances must update his knowledge. It aims to be able to understand the nature of village officials in RPJM, RKP, APB, up to the village accountability report. Langkat Governance also coordinates with the village regarding providing assistance and training to increase the capacity of village officials.

\section{Conclusion}

The village that can run independently of development management not only to manage the entire asset resources owned by the village, but the village will also be able to fix the basic needs of citizens, livelihood needs, and to organize the fight for citizens in a sustainable manner. The status and authority of the village is an important element to realize the independence of the village. The challenge facing the village from the start RPJM, RKP, APB and village accountability reports. Langkat governance also coordinate with the village regarding providing assistance and training to increase the capacity of village officials

\section{References}

[1]. Rusiadi, A. Novalina, P. Khairani and A. P. U. Siahaan, "Indonesia Macro Economy Stability Pattern Prediction (MundellFlamming Model)," IOSR Journal of Economics and Finance (IOSR-JEF), vol. 7, no. 5, pp. 6-23, 2016.

[2]. E. Sutoro, "Mempertegas Politik dan Kewenangan Desa," in Sarasehan Nasional Menggagas Masa Depan Desa, Jakarta, 2006.

[3]. Hudayana, Bambang and T. P. FPPD, "Peluang Pengembangan Partisipasi Masyarakat melalui Kebijakan Alokasi Dana Desa, Pengalaman Enam Kabupaten," in Forum Pengembangan Partisipasi Masyarakat (FPPM, Lombok, 2005.

[4]. Abdullah, Syukriy and A. Halim, "Studi atas Belanja Modal pada Anggaran Pemerintah dalam Hubungannya dengan Belanja Pemeliharaan dan Sumber Pendapatan," Jurnal Akuntansi Pemerintahan, vol. 2, no. 2, pp. 1-18, 2006.

[5]. Sari, Puspita, Noni, Yahya and Idhar, "Pengaruh Dana Alokasi Umum dan Pendapatan Asli Daerah terhadap Belanja Langsung," Jurnal Akuntansi Pemerintahan, vol. 42, no. 42, pp. 359-363, 2009.

[6]. U.-U. R. Indonesia, Pajak Daerah dan Retribusi Daerah., vol. 34, 2000.

[7]. Mardiasmo, Akuntansi Sektor Publik, Yogyakarta: Andi Offset, 2009.

[8]. D. Nordiawan, Akuntansi Sektor Publik., Jakarta: Salemba Empa, 2006.

[9]. Shim and Siegel, Accounting Hand-book, New York: Barron"s Educational Series, 2000.

[10]. H. Abdul, Akuntansi Keuangan Daerah, Jakarta: Salemba Empat, 2007. 